УДК 633.15:631.5(470.620)

06.01.00 Агрономия

РЕСУРСО- И ЭНЕРГОСБЕРЕГАЮЩИЕ ТЕХНОЛОГИИ ВЫРАЩИВАНИЯ КУКУРУЗЫ В УСЛОВИЯХ ЗАПАДНОГО ПРЕДКАВКАЗЬЯ

Радионов Алексей Иванович

д. с.-Х.н., профессор

Сысенко Инна Сергеевна

к. с.-Х. Н., доцент

Логойда Тимофей Владимирович

к. с.-х. н., доцент

Петрик Галина Федоровна

к. с.-Х. Н., доцент

Кубанский государственный аграрный университет, Краснодар, Россия

В статье рассмотрены различные технологии выращивания кукурузы на зерно с применением различных фонов почвенного плодородия, норм удобрений, системы защиты растений от сорняков, вредителей и болезней при рекомендуемой обработке почвы

Ключевые слова: ПЛОДОРОДИЕ ПОЧВЫ, СИСТЕМА УДОБРЕНИЯ, СИСТЕМА ЗАЩИТЫ РАСТЕНИЙ, СПОСОБ ОСНОВНОЙ ОБРАБОТКИ ПОЧВЫ, УРОЖАЙНОСТЬ

Doi: 10.21515/1990-4665-138-011
UDC 633.15:631.5(470.620)

Agronomy

\section{RESOURCE - SAVING TECHNOLOGIES OF GROWING CORN IN THE CONDITIONS OF THE WESTERN CISCAUCASIA}

\author{
Radionov Alexey Ivanovich \\ Dr.Sci.Arg., Professor \\ Sysenko Inna Sergeevna, \\ Cand.Agr.Sci., associate Professor \\ Logoyda Timofey Vladimirovich, \\ Cand.Agr.Sci., associate Professor \\ Petrik Galina Fedorovna, \\ Cand.Agr.Sci., associate Professor \\ Kuban state agrarian University, Krasnodar, Russia,
}

In the article we consider various technologies of growing corn for grain with application of various backgrounds of soil fertility, fertilizer norms, system of plant protection from weeds, pests and diseases with the recommended soil cultivation

Keywords: FERTILITY OF SOILS, FERTILIZER SYSTEM, PLANT PROTECTION SYSTEM, METHOD OF MAIN SOIL TREATMENT, YIELD

Кукуруза - одна из самых ценных сельскохозяйственных культур в мире по своим кормовым и продуктивным качествам. Мировое производство зерна кукурузы колеблется в пределах 600-700 млн. т. Её доля в мировом балансе составляет 31 \% (для сравнения - пшеницы 27 \%, ячменя $7 \%) / 4,6 /$.

Это культура пищевого и кормового направления, из зерна которой можно приготовить более 250 видов пищевых изделий. Из зерна кукурузы получают: крупу, консервы, кукурузные хлопья, муку, крахмал, патоку, глюкозу, спирт, сиропы, мед, пиво и многие другие продукты. Из зародышей, которые являются отходами винокуренного и мукомольного производства, добывают пищевое масло хорошего качества. Из стеблей, стерж- 
ней и обверток початков в химической и строительной промышленности вырабатывается более 40 видов различной продукции - изоляционные прокладки, линолеум, целлюлоза, фурфурол, клей, бумагу, вискозу, активированный уголь, искусственный пробковый материал, пластмассу и другие / $1,2 /$.

Особую ценность кукуруза представляет как высокоурожайное кормовое растение разностороннего использования. В животноводстве на корм скоту используют кукурузное зерно, силос, солому, зеленую массу. Зерно кукурузы является высококалорийным кормом - в 1 кг его содержится 1,34 кормовой единицы. Оно богато жирами, легко усвояемыми углеводами, содержит мало клетчатки. В зерне желтозерных сортов много каротина. Также зерно охотно поедается животными, оно является ценным компонентом комбикормов. В зерне содержится 65-70 \% углеводов, 9-12 \% белка, 4-8 \% жира, минеральные соли, витамины, незаменимые аминокислоты, безазотистые экстративные и другие полезные вещества. Около 20 \% производимого в мире зерна кукурузы используется на продовольственные цели / 1, 2, 3 /.

Возделывание кукурузы имеет важное хозяйственноорганизационное и агротехническое значение. При высокой агротехнике кукуруза как пропашная культура оставляет после себя хорошо очищенное от сорняков поле. При уборке на зерно является хорошим предшественником под яровые культуры, а на зеленый корм - прекрасной парозанимающей культурой и одним из лучших предшественников под озимые культуры / 4, 5 /.

Однако в последние годы в крае неоправданно сократились площади кукурузы, снизилась урожайность зерна и зеленой массы этой культуры, возросли материально-денежные затраты на ее возделывание.

Снижение урожайности зерна кукурузы связано не только с участившимися засухами, но и со слабой оснащенностью хозяйств новой тех- 
никой, высокой стоимостью энергоресурсов, минеральных удобрений, средств защиты растений от вредных патогенов. Вследствие этого материальные ресурсы стали малодоступны для большинства хозяйств, что привело к повышению засоренности посевов, снижению культуры земледелия, ухудшению условий питания растений, ошибкам в технологии возделывания кукурузы.

Изменение этой ситуации должно происходить за счет совершенствования, как отдельных приемов выращивания, так и всей технологии в целом, основанной на эффективном использовании природных, биологических и трудовых ресурсов. Краснодарский край отличается большим разнообразием природно-экономических условий, что предопределяет необходимость дифференцированного подхода к выбору технологии возделывания кукурузы.

В связи с этим цель нашего опыта заключалась в изучении влияния различных технологий выращивания (от экстенсивной, ресурсосберегающей, беспестицидной до интенсивной) на продуктивность кукурузы на зерно на территории учхоза «Кубань», расположенного в центральной зоне Краснодарского края на черноземе выщелоченном при рекомендуемой основной обработке почвы.

Исследования такой тематики проводятся нами в длительном стационарном многофакторном опыте в трех ротациях севооборота: 19941996 гг. (1-я ротация); 2005-2007 гг. (2-я ротация) и 2016-2018 гг. (3-я ротация) на опытной станции Кубанского ГАУ.

Опытное поле, на котором проводились наши исследования расположено на территории учхоза «Кубань», принадлежащего Кубанскому государственному аграрному университету.

Рельеф опытного поля - равнинный. Почвы представлены черноземом выщелоченным сверхмощным легкоглинистым со средней мощностью гумусового горизонта - 147 сантиметров. Механический состав - 
легкоглинистый. Почвообразующими породами послужили лессовидные тяжелые суглинки с реакцией водной среды от 6,5 до 8,2.

Анализ почв опытного поля, проведенный институтом КубаньНИИгипрозем в 1991 году показал, что содержание гумуса в пахотном слое небольшое и колеблется от 2,5 до 2,9 \%, однако, в связи с большой мощностью гумусового горизонта А + В (147 см) валовые запасы его составляют - 407 т/га, а в двухметровом слое -457 т/га.

Центральная зона Краснодарского края, где проводились наши исследования, по температурному режиму и условиям увлажнения характеризуется умеренно-континентальным, умеренно-влажным и теплым климатом.

Среднегодовая температура воздуха составляет $10,0-10,8^{0} \mathrm{C}$, а наиболее холодного месяца января $-1,5-3,5^{\circ} \mathrm{C}$. Продолжительность безморозного периода составляет 175 - 225 дней.

Первая половина осени - сухая, вторая - влажная. Зима - умеренномягкая, с частыми оттепелями. Весна - ранняя, затяжная, с медленным нарастанием тепла. Лето - жаркое, часто засушливое.

Преобладающими ветрами на территории являются восточные и западные. Неблагоприятное влияние на климат оказывают северо-восточные и восточные ветры, обуславливающие летом сухость и высокую температуру воздуха, а весной иссушение пахотного горизонта и пыльные бури. Количество дней со слабыми суховеями за теплый период - 47 дней, в том числе с интенсивными - 5 дней.

Таким образом, климатические условия данной зоны позволяют выращивать многие сельскохозяйственные культуры, в том числе люцерну и получать высокие урожаи ее зеленой массы.

По погодным условиям годы проведения опыта по ротациям севооборота отличались друг от друга и имели свои особенности. 
За сельскохозяйственные годы первой ротации севооборота 19931994, 1994-1995, 1995-1996 осадков выпало соответственно 543, 826, 704 мм, т.е. больше в 1994-1995 с/х году на 122 мм (17\%), чем в 1995-1996 c/х году и на 283 мм (52 \%), чем в 1993-1994 с/х году. При этом, за вегетационный период кукурузы осадков выпало 199 мм (1994 г.), 401 мм (1995 г.), 360 мм (1996 г.), что на 66 мм (33 \%) меньше нормы в 1994 году, на 136 мм $(51 \%)$ и 95 мм (36\%) соответственно годам больше нормы.

За сельскохозяйственные годы второй ротации севооборота 20042005, 2005-2006, 2006-2007 осадков выпало соответственно 750, 759, 588 мм, т.е. больше в 2005-2006 с/х году на 9 мм (1\%), чем в 2004-2005 c/x году и на 171 мм (29 \%), чем в 2005-2006 с/х году. При этом, за вегетационный период кукурузы осадков выпало 273 мм (2005 г.), 304 мм (2006 г.), 122 мм (2007 г.), что на 7 мм (3 \%) и 158 мм (130\%) меньше нормы в 2005 и 2007 годах соответственно и на 24 мм (9 \%) больше нормы, чем в 2006 году.

За сельскохозяйственные годы третьей ротации севооборота 20152016, 2016-2017 осадков выпало соответственно 756, 693 мм, т.е. больше в 2015-2016 с/х году на 63 мм (9 \%), чем в 2016-2017 с/х году. При этом, за вегетационный период кукурузы осадков выпало 290 мм (2016 г.), 337 мм (2017 г.), что соответственно на 21 мм (8 \%) и 68 мм (25\%) больше нормы.

Таким образом, можно сказать, что в годы исследований, погодные условия для роста, развития и продуктивности зерновой кукурузы складывались неудовлетворительно (1996, 2007 гг.), удовлетворительно (1994, 2005, 2006 гг.) и хорошо (1995, 2016, 2017 гг.), позволяя формировать урожайность культуры различного уровня.

Наша работа является частью научно-исследовательской работы, проводимой в длительном стационарном опыте, заложенном в КубГАУ в 1991 году.

Схема опыта представляет собой часть выборки из полной схемы многофакторного опыта $(4 \times 4 \times 4) \times 3$. 
Стационарный многофакторный опыт представлен следующими факторами: уровень плодородия (фактор А); система удобрения (фактор $\mathrm{B}$ ); система защиты растений (фактор С), способ основной обработки почвы (фактор Д).

При кодировании вариантов принята специальная символика, в которой в условных единицах обозначены первой цифрой - уровень почвенного плодородия (0 - исходный; 1 - средний; 2 - повышенный; 3 - высокий), второй - норма удобрения (0 - без удобрений; 1 - минимальная; 2 средняя; 3 - высокая), третьей - система защиты растений (0 - без применения средств защиты растений; 1 - биологическая защита от вредителей и болезней; 2 - химическая защита от сорняков; 3 - интегрированная защита от сорняков, вредителей и болезней).

Уровень плодородия (фактор А) создавался в 1991 году (1я ротация севооборота), в 2003 году (2я ротация севооборота) и в 2015 году (3я ротация севооборота) путем последовательного внесения возрастающих доз органических удобрений (полуперепревшего навоза КРС) и фосфора на основе существующих нормативных показателей по плодородию почвы, внесением в почву при: $\mathrm{A}_{1}-200$ кг/га $\mathrm{P}_{2} \mathrm{O}_{5}$ и 200 т/га подстилочного навоза; при $\mathrm{A}_{2}$ - дозы удваиваются; при $\mathrm{A}_{3}$ - утраиваются.

Изучаемые факторы и их рубрикация представлены в таблице 1. 
Таблица 1 - СХЕМА ОПЫТА

\begin{tabular}{|c|c|c|c|}
\hline $\begin{array}{c}\text { Вариант } \\
\text { опыта } \\
\end{array}$ & $\begin{array}{c}\text { Уровень } \\
\text { плодородия (A) }\end{array}$ & $\begin{array}{c}\text { Система } \\
\text { удобрения (B) }\end{array}$ & $\begin{array}{c}\text { Система защиты } \\
\text { растений }(\mathrm{C})\end{array}$ \\
\hline 000 (к) & $\begin{array}{c}\text { исходный фон } \\
\text { плодородия }\left(\mathrm{A}_{0}\right)\end{array}$ & без удобрений $\left(\mathrm{B}_{0}\right)$ & $\begin{array}{c}\text { без средств защиты } \\
\text { растений }\left(\mathrm{C}_{0}\right)\end{array}$ \\
\hline 111 & $\begin{array}{c}\text { средний фон плодо- } \\
\text { родия (200 т/га наво- } \\
\text { за + } 200 \text { кг/га } \mathrm{P}_{2} \mathrm{O}_{5} ; \\
\left.\mathrm{A}_{1}\right)\end{array}$ & $\begin{array}{c}\text { минимальная доза } \\
\left(\mathrm{N}_{30} \mathrm{P}_{30}+20 \text { т/га }\right. \\
\left.\text { навоза; } \mathrm{B}_{1}\right)\end{array}$ & $\begin{array}{c}\text { биологическая система } \\
\text { защиты растений } \\
\left.\text { (биопрепараты; } \mathrm{C}_{1}\right)\end{array}$ \\
\hline 222 & $\begin{array}{c}\text { повышенный фон } \\
\text { плодородия (400 т/га } \\
\text { навоза+400 кг/га } \\
\left.\mathrm{P}_{2} \mathrm{O}_{5} ; \mathrm{A}_{2}\right) \\
\end{array}$ & $\begin{array}{c}\text { средняя доза }\left(\mathrm{N}_{60} \mathrm{P}_{60+}\right. \\
\left.40 \text { т/га навоза; } \mathrm{B}_{2}\right)\end{array}$ & $\begin{array}{c}\text { химическая система защи- } \\
\text { ты растений от сорняков } \\
\left(\mathrm{C}_{2}\right)\end{array}$ \\
\hline 333 & $\begin{array}{c}\text { высокий фон плодо- } \\
\text { родия (600 т/га наво- } \\
\text { за + } 600 \text { кг/га } \mathrm{P}_{2} \mathrm{O}_{5} ; \\
\left.\mathrm{A}_{3}\right)\end{array}$ & $\begin{array}{c}\text { высокая доза }\left(\mathrm{N}_{120} \mathrm{P}_{120}+\right. \\
\left.80 \text { т/га навоза; } \mathrm{B}_{3}\right)\end{array}$ & $\begin{array}{c}\text { интегрированная система } \\
\text { защиты растений от сорня- } \\
\text { ков, вредителей и болезней } \\
\left(\mathrm{C}_{3}\right) \\
\end{array}$ \\
\hline 002 & $\begin{array}{c}\text { исходный фон } \\
\text { плодородия }\left(\mathrm{A}_{0}\right)\end{array}$ & без удобрений $\left(\mathrm{B}_{0}\right)$ & $\begin{array}{c}\text { химическая система защи- } \\
\text { ты растений от сорняков } \\
\left(\mathrm{C}_{2}\right)\end{array}$ \\
\hline 020 & $\begin{array}{c}\text { исходный фон } \\
\text { плодородия }\left(\mathrm{A}_{0}\right)\end{array}$ & $\begin{array}{c}\text { средняя доза }\left(\mathrm{N}_{60} \mathrm{P}_{60^{+}}\right. \\
\left.40 \text { т/га навоза; } \mathrm{B}_{2}\right)\end{array}$ & $\begin{array}{c}\text { без средств защиты } \\
\text { растений }\left(\mathrm{C}_{0}\right) \\
\end{array}$ \\
\hline 022 & $\begin{array}{c}\text { исходный фон } \\
\text { плодородия }\left(\mathrm{A}_{0}\right)\end{array}$ & $\begin{array}{c}\text { средняя доза }\left(\mathrm{N}_{60} \mathrm{P}_{60+}\right. \\
\left.40 \text { т/га навоза; } \mathrm{B}_{2}\right)\end{array}$ & $\begin{array}{c}\text { химическая система защи- } \\
\text { ты растений от сорняков } \\
\left(\mathrm{C}_{2}\right)\end{array}$ \\
\hline 200 & $\begin{array}{c}\text { повышенный фрон } \\
\text { плодородия (400 т/га } \\
\text { навоза+400 кг/га } \\
\left.\mathrm{P}_{2} \mathrm{O}_{5} ; \mathrm{A}_{2}\right) \\
\end{array}$ & без удобрений $\left(\mathrm{B}_{0}\right)$ & $\begin{array}{c}\text { без средств защиты } \\
\text { растений }\left(\mathrm{C}_{0}\right)\end{array}$ \\
\hline 202 & $\begin{array}{c}\text { повышенный фон } \\
\text { плодородия (400 т/га } \\
\text { навоза+400 кг/га } \\
\left.\mathrm{P}_{2} \mathrm{O}_{5} ; \mathrm{A}_{2}\right) \\
\end{array}$ & без удобрений $\left(\mathrm{B}_{0}\right)$ & $\begin{array}{c}\text { химическая система защи- } \\
\text { ты растений от сорняков } \\
\left(\mathrm{C}_{2}\right)\end{array}$ \\
\hline 220 & $\begin{array}{c}\text { повышенный фрон } \\
\text { плодородия (400 т/га } \\
\text { навоза+400 кг/га } \\
\left.\mathrm{P}_{2} \mathrm{O}_{5} ; \mathrm{A}_{2}\right) \\
\end{array}$ & $\begin{array}{c}\text { средняя доза }\left(\mathrm{N}_{60} \mathrm{P}_{60+}\right. \\
\left.40 \text { т/га навоза; } \mathrm{B}_{2}\right)\end{array}$ & $\begin{array}{c}\text { без средств защиты } \\
\text { растений }\left(\mathrm{C}_{0}\right)\end{array}$ \\
\hline
\end{tabular}

При описании результатов исследований приняты условные названия технологий выращивания: 000 - экстенсивная; 111 - беспестицидная; 222 - экологически допустимая; 333 - интенсивная. В качестве контроля служил вариант 000.

Общая площадь делянки - 4,2 м х 25 м $=105 \mathrm{~m}^{2}$, учетная - 2,8 м х 17м $=47,6 \mathrm{~m}^{2}$. Повторность опыта - трехкратная.

В опыте соответственно ротациям севооборота выращивались следующие гибриды кукурузы Краснодарский 382 МВ, Краснодарский 385 
МВ и Краснодарский 282 АМВ районированные во всех зонах Краснодарского края. Предшественник кукурузы - озимая пшеница.

После уборки озимой пшеницы на всех вариантах опыта проводили двукратное лущение (ДТ-75М+БДТ-3) на глубину 6-8 см. Затем по мере отрастания сорняков почву дисковали еще два раза на глубину 6-10 и 10-12 см агрегатом МТЗ-80+БДТ-3.

Основная обработка почвы проводилась в первой декаде октября и была следующей в первой и второй ротациях: - рекомендуемая обработка почвы состояла из обработки БДТ-3,0 на глубину 8-10 см, корпусного лущения ПЛ-5-25 на глубину 10-12 см и зяблевой вспашки агрегатом ДТ75М+ПЛН-4-35 на глубину 23-25 см; в третьей ротации - рекомендуемая обработка почвы состояла из обработки дисковером фирмы Кун на глубину 8-10 см, корпусного лущения на глубину 10-12 см и зяблевой вспашки агрегатом МТЗ-1221+ПО 4-40 Кун-Мультимастер на глубину 23-25 см.

Под основную обработку почвы вносился полуперепревший навоз КРС агрегатом МТЗ-80+РОУ-6 и минеральные удобрения (аммиачная селитра, двойной суперфосфат) вручную, в нормах согласно схемы опыта с последующей заделкой их в почву дисковой бороной.

Весной при наступлении физической спелости почвы, с целью уничтожения всходов сорняков и выравнивания поверхности почвы проводилось две культивации: первая - на глубину 8-10 см (агрегатом ДТ75М+2КПС-4+БЗСС-1,0) и вторая (предпосевная) на глубину 6-8 см агрегатом ДТ-75М+КРН-4,2+ЗБ3Т-1-10. Одновременно с предпосевной культивацией только на вариантах $\mathrm{C}_{2}$ и $\mathrm{C}_{3}$ в первой ротации вносился почвенный гербицид Харнес в дозе 2,5 л/га с нормой рабочего раствора 200 л/га; во второй ротации гербицид Харнес в дозе 2,5 л/га, а в течение вегетации (фаза 3-5 листьев) - гербицид Базис в дозе 25 г/га + прилипатель Тренд (0,4 л/га); в третьей ротации - в фазе 3-5 листьев у кукурузы - гербицид Элюмис в дозе 1,6 л/га. 
На контроле и вариантах с применением биологических средств защиты растений $\left(\mathrm{C}_{0}\right.$ и $\left.\mathrm{C}_{1}\right)$ предусматривалась ручная прополка, которая проводилась дважды за вегетацию кукурузы, в те же сроки, что и междурядные культивации.

Согласно методике посев проводился протравленными семенами (ТМТД + витавакс $(1,5+1,5$ кг/т) + NаКМЦ-0,2 кг/т). В 1994 году - 8 мая, в 1995 и 1996 годах - 28 апреля, в 2005 году - 22 апреля, в 2006 - 24 апреля, в 2007 году - 22 апреля сеялкой СПЧ-6. В 2016 году семена протравливали (максим $\mathrm{O}_{25}$ ФС+апрон XL+круизер ФС 350+седирет (500+300+1042+300 мл/100 кг)) и посев проводили - 19 апреля. В 2017 году семена протравливали (максим XL (1 л/т) + Форс Zea (125 мл/1 посевную единицу - 80 тыс. семян), а посев проводили - 18 апреля сеялкой Госпардо SP 8. Норму высева семян устанавливали из расчета 4-5 всхожих семян на 1 пог. метр рядка (70 тыс. семян на 1 га или 24 кг). Глубина заделки семян - 6-8 см. После посева почва прикатывалась кольчато-шпоровыми катками.

За вегетационный период кукурузы проводились две междурядные обработки культиватором КРН-4,2: первая в фазу 2-3х листьев, а вторая - в фазу 7-9 листьев.

На варианте с интегрированной системой защиты растений от вредителей и болезней $\left(\mathrm{C}_{3}\right)$ за вегетационный период кукурузы в 1994 и 1996 годах была проведена одна обработка против долгоносиков в фазе 2-3-х листьев препаратом децис в дозе 0,25 л/га, а в 1996 году провели такую же обработку, а также в фазе выметывания против стеблевого мотылька и хлопковой совки проводили опрыскивание посевов препаратом антио в дозе 2,5 л/га.

На варианте с интегрированной системой защиты растений $\left(\mathrm{C}_{3}\right)$ за вегетационный период кукурузы в 2005 году была проведена одна обработка против стеблевого мотылька и хлопковой совки в фазе выметывания системным препаратом БИ-58 в дозе 1,0 л/га. В 2006 году не была прове- 
дена ни одна обработка против вредителей и болезней, так как степень развития и распространения вредных организмов была ниже экономического порога их вредоносности и проведение обработок было не целесообразным. В 2007 году была проведена одна обработка препаратом каратезеон в дозе 0,2 л/га против кукурузного мотылька в фазе выметывания.

На варианте с биологической системой защиты растений $\left(\mathrm{C}_{1}\right)$ за вегетацию кукурузы в первой ротации севооборота, 2005 и 2006 годах не было проведено ни одной обработки биопрепаратами, так как численность вредителей и развитие болезней не превышали экономический порог вредоносности. В 2007, 2016 и 2017 годах году обработку проводили энтомологической смесью (5 л/га) против кукурузного мотылька в фазе выметывания.

Уборка кукурузы на зерно проводилась в начале сентября вручную со всей учетной площади каждой делянки.

В последнее время положение в кукурузоводческой отрасли ухудшилось, уменьшилось количество вносимых удобрений, что приводит к обеднению почв органическим веществом. Поэтому в наших исследованиях, наряду с совершенствованием приемов выращивания кукурузы, большое внимание уделялось экологическим, биологическим, энерго- и ресурсосберегающим технологиям. Практическая значимость таких исследований заключается в том, чтобы предложить кукурузосеющим хозяйствам альтернативные технологии, в зависимости от обеспеченности их удобрениями, средствами защиты растений, ГСМ и т.д., обеспечивающие получение устойчивых урожаев кукурузы при одновременном удовлетворении природоохранных требований. Это связано с тем, что применение интенсивной технологии в настоящее время экономически не оправдано. В годы, неблагоприятные по увлажнению, интенсивная технология возделывания кукурузы не обеспечивает той прибавки урожая, на которую рассчитываются применяемые агроприемы. 
Основным показателем, определяющим уровень урожайности кукурузы, является индивидуальная продуктивность растений, а также элементы его структуры. Изучение структуры урожая в связи с условиями выращивания позволяет вскрыть слабые звенья в используемой системе агротехнических мероприятий, с тем, чтобы постоянно совершенствовать их, в наибольшей мере используя природные условия и приемы возделывания для получения высокого урожая, придавая ему нужную структуру,

По нашим данным элементы структуры урожая и в целом урожайность зерна кукурузы в первой ротации севооборота значительно отличались по годам в зависимости от условий увлажнения. Если в 1995 году в период вегетации кукурузы выпало 401 мм осадков, что на 202 мм (102 \%) и 41 мм (11\%) соответственно больше, чем в 1994 и 1996 годах, то и показатели продуктивности растений в этот год были значительно выше. Однако, следует отметить, что несмотря на достаточно большое количество осадков в 1996 году (360 мм при норме 265 мм) в июле месяце (критический период по водопотреблению) осадков не было вообще поэтому и продуктивность кукурузы была самой низкой. Так, например наибольшие масса початка $(207,4$ г), масса зерна с початка $(178,9$ г), масса зерна с растения (169,9 г), масса 1000 зерен (291 г) и выход зерна с початка (86,2 \%) получены в 1995 году. Разница соответственно показателям с 1994 и 1996 годами составила 104,2-141,5 г (101-142\%); 91,3-126,3 г (104-240 \%); 82,3117,3 г (94-223 \%); 86-150 г (42-106 \%) и 5,3-6,6 \% (таблица 1).

Анализируя полученные данные можно отметить, что длина початка кукурузы по мере интенсификации технологии выращивания (от 111 к 333) увеличивалась по сравнению с контролем на 0,9-2,5 см (6-18 \%), озерненность початка на 38-116 шт. (9-29 \%), масса початка на 7,8-29,6 г (7-27 \%), масса зерна с початка на 7,6-27,6 г (8-30 \%), масса зерна с растения на 7,427,0 г (8-30 \%), масса 1000 зерен на 7-19 г (3-9 \%), выход зерна с початка 
на 1,5-3,0 \%. Обратная тенденция отмечена при определении длины невыполненной части початка - она от 111 к 333 уменьшалась на 0,1-0,6 см (6$35 \%)$.

Таблица 1 - ЭЛЕМЕНТЫ СТРУКТУРЫ УРОЖАЯ КУКУРУЗЫ В ЗАВИСИМОСТИ ОТ ТЕХНОЛОГИИ ВЫРАЩИВАНИЯ, 1994-1996 ГГ.

\begin{tabular}{|c|c|c|c|c|c|c|c|c|}
\hline \multirow[b]{2}{*}{$\begin{array}{c}\text { Индекс } \\
\text { вариан- } \\
\text { та опыта }\end{array}$} & \multicolumn{2}{|c|}{ Длина, см } & \multirow{2}{*}{ 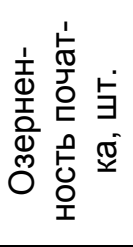 } & \multicolumn{4}{|c|}{ Macca, г } & \multirow{2}{*}{ 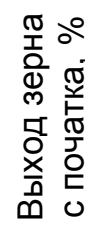 } \\
\hline & $\begin{array}{c}\text { почат- } \\
\text { ка }\end{array}$ & $\begin{array}{c}\text { невыпол- } \\
\text { ненной } \\
\text { части по- } \\
\text { чатка }\end{array}$ & & $\begin{array}{c}\text { почат- } \\
\text { ка }\end{array}$ & $\begin{array}{l}\text { зерна с } \\
\text { початка }\end{array}$ & $\begin{array}{c}\text { зерна с } \\
\text { растения }\end{array}$ & $\begin{array}{c}1000 \\
\text { зерен }\end{array}$ & \\
\hline 000 (к) & 13,9 & 1,7 & 402 & 111,0 & 92,6 & 89,9 & 203 & 81,7 \\
\hline 111 & 14,8 & 1,6 & 446 & 118,8 & 100,2 & 97,3 & 210 & 83,2 \\
\hline 222 & 15,5 & 1,4 & 482 & 131,7 & 112,2 & 109,1 & 215 & 84,3 \\
\hline 333 & 16,4 & 1,1 & 518 & 140,6 & 120,2 & 116,9 & 222 & 84,7 \\
\hline 002 & 13,4 & 1,9 & 396 & 115,4 & 96,1 & 93,3 & 207 & 81,9 \\
\hline 020 & 15,1 & 1,4 & 471 & 128,8 & 110,1 & 107,0 & 215 & 84,5 \\
\hline 022 & 15,0 & 1,4 & 462 & 127,9 & 108,9 & 105,9 & 213 & 84,1 \\
\hline 200 & 14,8 & 1,5 & 467 & 125,3 & 106,3 & 103,3 & 213 & 83,9 \\
\hline 202 & 14,5 & 1,4 & 448 & 124,4 & 105,0 & 102,1 & 212 & 83,3 \\
\hline 220 & 15,8 & 1,4 & 497 & 131,0 & 111,9 & 108,8 & 216 & 84,5 \\
\hline
\end{tabular}

В результате проведенных исследований установлено, что внесение средней дозы удобрений на вариантах 020 и 022 в среднем повышало данные показатели по сравнению с контролем сильнее, чем применение повышенного фона почвенного плодородия на вариантах 200 и 202. Так, длина початка на вариантах 020 и 022 увеличивалась на 1,2 см (9\%), озерненность початка на 65 шт. (16 \%), масса початка на 17,4 г (16\%), масса зерна с початка на 16,9 г (18\%), масса зерна с растения на 16,6 г (18\%), масса 1000 зерен на 11 г (5 \%), выход зерна с початка на 2,6 \%. Превышение данных показателей на вариантах 200 и 202, по сравнению с контролем составило соответственно: 0,8 см (6 \%), 56 шт. (14\%), 13,9 г (13\%), 13,1 г (14\%), 12,8 г (14 \%), 10 г (5 \%), 1,9 \%. Лучшие результаты были получены 
на варианте 220 (повышенный фон почвенного плодородия и средняя доза удобрений).

Множественный коэффициент корреляции был достаточно большой $(\mathrm{R}=0,83-0,98)$, что говорит о высокой зависимости данных показателей от изучаемых факторов. Результатами пошагового множественного регрессионного анализа установлено, что наибольшая зависимость элементов структуры урожая получена от погодных условий, где доля влияния составила по показателям 45,8-84,1\%, далее было влияние системы удобрения $38,3-50,3 \%$, уровня почвенного плодородия 24,2-36,1 \%, на последнем месте было влияние системы защиты растений 3,4-20,5 \% (таблица 2). Таблица 2 - МНОЖЕСТВЕННАЯ РЕГРЕССИОННАЯ ЗАВИСИМОСТЬ ЭЛЕМЕНТОВ СТРУКТУРЫ УРОЖАЯ КУКУРУЗЫ В ЗАВИСИМОСТИ ОТ ТЕХНОЛОГИИ ВЫРАЩИВАНИЯ, 1994-1996 гг.

\begin{tabular}{|c|c|c|c|c|c|}
\hline \multirow[t]{2}{*}{ Показатель } & \multicolumn{4}{|c|}{$\begin{array}{c}\text { Доли влияния и коэфрфициенты } \\
\text { регрессии по факторам }\end{array}$} & \multirow[t]{2}{*}{$\mathrm{R}$} \\
\hline & $A$ & B & $\mathrm{C}$ & $\Pi$ & \\
\hline Длина початка, см & $\frac{32,8}{0,51}$ & $\frac{47,3}{0,71}$ & $\frac{18,0}{-0,30}$ & $\frac{51,3}{2,45}$ & 0,98 \\
\hline $\begin{array}{l}\text { Длина невыполненной } \\
\text { части початка, см }\end{array}$ & $\frac{36,1}{-0,10}$ & $\frac{44,3}{-0,13}$ & $\frac{3,4}{-0,00}$ & $\frac{4,8}{0,10}$ & 0,84 \\
\hline Озерненность початка, шт. & $\frac{35,8}{27,1}$ & $\frac{45,6}{34,08}$ & $\frac{15,1}{-12,23}$ & $\frac{45,8}{101,7}$ & 0,97 \\
\hline Масса початка, г & $\frac{34,3}{4,83}$ & $\frac{48,2}{6,58}$ & $\frac{8,6}{1,58}$ & $\frac{75,8}{71,06}$ & 0,91 \\
\hline Масса зерна с початка, г & $\frac{34,3}{4,64}$ & $\frac{50,3}{6,56}$ & $\frac{6,8}{1,34}$ & $\frac{75,7}{63,66}$ & 0,91 \\
\hline Масса зерна с растения, г & $\frac{34,2}{4,54}$ & $\frac{50,1}{6,41}$ & $\frac{6,8}{1,31}$ & $\frac{75,7}{59,19}$ & 0,91 \\
\hline Масса 1000 зерен, г & $\frac{34,2}{4,39}$ & $\frac{41,0}{5,14}$ & $\frac{13,0}{-2,03}$ & $\frac{84,1}{75,69}$ & 0,88 \\
\hline Выход зерна с початка, \% & $\frac{24,2}{1,86}$ & $\frac{38,3}{2,21}$ & $\frac{20,5}{-1,76}$ & $\frac{45,8}{3,69}$ & 0,83 \\
\hline
\end{tabular}

Примечание: А-уровень плодородия почвы; В-система удобрений; С-система защиты растений; П - погодные условия. Над чертой - доля влияния (\%), под чертой - коэффициент регрессии. 
Во второй ротации севооборота также значительное влияние на рост, развитие и урожайность зерна кукурузы оказывали погодные условия. Так, в 2005 и 2006 годах в период вегетации кукурузы выпало соответственно 283 и 304 мм осадков, что на 151-182 мм (124-149 \%) больше, чем в 2007 году. Наименьшие масса початка (111,3 г), масса зерна с початка (88,3 г), масса зерна с растения (86,5 г), масса 1000 зерен (235 г) и выход зерна с початка (79,4 \%) получены в 2007 году. Разница соответственно показателям с 2005 и 2006 годами составила 124,9-106,6 г (112-96 \%); 103,7-73,7 г (117-83 \%); 99,7-98,1 г (115-113\%); 109-137 г (46-58 \%) (таблица 3).

Таблица 3 - ЭЛЕМЕНТЫ СТРУКТУРЫ УРОЖАЯ КУКУРУЗЫ В ЗАВИСИМОСТИ ОТ ТЕХНОЛОГИИ ВЫРАЩИВАНИЯ, 2005-2007 ГГ.

\begin{tabular}{|c|c|c|c|c|c|c|c|c|}
\hline \multirow{2}{*}{$\begin{array}{c}\text { Индекс } \\
\text { вариан- } \\
\text { та опыта }\end{array}$} & \multicolumn{2}{|c|}{ Длина, см } & \multirow{2}{*}{ 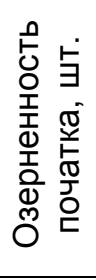 } & \multicolumn{4}{|c|}{ Macca, г } & \multirow{2}{*}{ 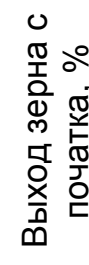 } \\
\hline & $\begin{array}{c}\text { почат- } \\
\text { ка }\end{array}$ & $\begin{array}{c}\text { полнен- } \\
\text { ной час- } \\
\text { ти почат- } \\
\text { ка }\end{array}$ & & $\begin{array}{c}\text { почат- } \\
\text { ка }\end{array}$ & $\begin{array}{l}\text { зерна с } \\
\text { початка }\end{array}$ & $\begin{array}{c}\text { зерна с } \\
\text { растения }\end{array}$ & $\begin{array}{c}1000 \\
\text { зерен }\end{array}$ & \\
\hline 000 (к) & 16,2 & 2,8 & 376 & 167,1 & 130,7 & 135,1 & 286,6 & 78,2 \\
\hline 111 & 17,8 & 2,5 & 444 & 179,8 & 139,0 & 143,7 & 306,2 & 77,3 \\
\hline 222 & 18,9 & 2,0 & 497 & 196,5 & 153,4 & 158,5 & 324,7 & 78,1 \\
\hline 333 & 20,6 & 1,0 & 651 & 217,9 & 174,3 & 180,4 & 360,1 & 80,0 \\
\hline 002 & 17,3 & 2,6 & 399 & 174,9 & 137,0 & 141,6 & 301,0 & 78,3 \\
\hline 020 & 18,3 & 2,3 & 472 & 185,5 & 144,5 & 149,5 & 312,4 & 77,9 \\
\hline 022 & 18,5 & 2,2 & 478 & 187,0 & 145,8 & 150,9 & 315,6 & 78,0 \\
\hline 200 & 18,6 & 2,1 & 482 & 189,4 & 148,2 & 153,4 & 319,0 & 78,2 \\
\hline 202 & 18,7 & 2,1 & 485 & 192,3 & 149,2 & 154,4 & 321,2 & 77,6 \\
\hline 220 & 18,8 & 2,0 & 494 & 194,2 & 151,6 & 156,8 & 323,2 & 78,1 \\
\hline
\end{tabular}

По нашим данным, длина початка кукурузы по мере интенсификации технологии выращивания (от 111 к 333) увеличивалась по сравнению с контролем на 1,6-4,4 см (10-27 \%), озерненность початка на 68-284 шт. (18$77 \%$ ), масса початка на 12,7-50,8 г (8-30 \%), масса зерна с початка на 8,343,6 г (6-33 \%), масса зерна с растения на 8,6-45,3 г (6-34 \%), масса 1000 
зерен на 19,6-73,5 г (7-26 \%). А вот длина невыполненной части початка уменьшалась от 111 к 333 на 0,3-1,8 см (11-64 \%).

Внесение средней дозы удобрений в среднем по вариантам 020 и 022, как и повышенного фона плодородия почвы на вариантах 200 и202 увеличивало данные показатели по сравнению с контролем. Так, длина початка соответственно вариантам опыта увеличивалась на 2,2-2,5 см (1415\%), озерненность початка на 99-108 шт. (27-29 \%), масса початка на 19,2-23,8 г (12-14 \%), масса зерна с початка на 14,5-18,0 г (12-14 \%), масса зерна с растения на 15,1-18,8 г (12-14 \%), масса 1000 зерен на 27,4-33,5 г (10-12 \%). Лучшие результаты были получены на варианте 220 (повышенный фон почвенного плодородия и средняя доза удобрений) и превышали контроль соответственно показателям на: 2,6 см (16 \%); 118 шт. (31\%); 27,1 г (16 \%); 20,9 г (16\%); 21,7 г (16\%); 36,6 г (13\%).

Множественный коэффициент корреляции был достаточно большой $(\mathrm{R}=0,88-0,95)$, что говорит о высокой зависимости данных показателей от изучаемых факторов. Исключение составляет влияние изучаемых факторов на выход зерна с початка $(\mathrm{R}=0,31)$. Результатами пошагового множественного регрессионного анализа установлено, что наибольшая зависимость элементов структуры урожая получена от уровня почвенного плодородия, где доля влияния составила по показателям 40,0-44,6 \%, далее было влияние системы удобрения 31,4-36,3 \%, на последнем месте было влияние системы защиты растений 11,8-18,9 \% (таблица 4).

В третьей ротации севооборота осадков выпало 290 мм (2016 г.) и 337 мм (2017 год), что больше нормы соответственно на 21-68 мм (8-25 \%). Однако, следует отметить, что несмотря на большое количество осадков в 2016 году (290 мм при норме 269 мм) в июле месяце (критический период по водопотреблению) их выпало всего 14 мм против 71 мм в 2017 году, поэтому и продуктивность кукурузы была ниже. 
ТабЛИца 4 - МНОЖЕСТВЕННАЯ РЕГРЕССИОННАЯ ЗАВИСИМОСТЬ ЭЛЕМЕНТОВ СТРУКТУРЫ УРОЖАЯ КУКУРУЗЫ В ЗАВИСИМОСТИ ОТ ТЕХНОЛОГИИ ВЫРАЩИВАНИЯ, 2005-2007 ГГ.

\begin{tabular}{|c|c|c|c|c|}
\hline \multirow[t]{2}{*}{ Показатель } & \multicolumn{3}{|c|}{$\begin{array}{c}\text { Доли влияния и коэфффициенты } \\
\text { регрессии по фракторам }\end{array}$} & \multirow[t]{2}{*}{$\mathrm{R}$} \\
\hline & $A$ & B & $\mathrm{C}$ & \\
\hline Длина початка, см & $\frac{41,8}{0,71}$ & $\frac{34,0}{0,59}$ & $\frac{16,8}{0,31}$ & 0,93 \\
\hline $\begin{array}{l}\text { Длина невыполненной } \\
\text { части початка, см }\end{array}$ & $\frac{42,8}{-0,31}$ & $\frac{31,8}{-0,23}$ & $\frac{17,1}{-0,13}$ & 0,92 \\
\hline Озерненность початка, шт. & $\frac{40,0}{48,94}$ & $\frac{36,3}{44,69}$ & $\frac{11,8}{16,94}$ & 0,88 \\
\hline Масса початка, г & $\frac{44,6}{9,31}$ & $\frac{33,0}{7,01}$ & $\frac{17,3}{3,88}$ & 0,95 \\
\hline Масса зерна с початка, г & $\frac{43,4}{7,48}$ & $\frac{32,6}{5,70}$ & $\frac{17,6}{3,23}$ & 0,94 \\
\hline Масса зерна с растения, г & $\frac{43,3}{7,81}$ & $\frac{32,5}{5,96}$ & $\frac{17,6}{3,38}$ & 0,93 \\
\hline Масса 1000 зерен, г & $\frac{42,8}{12,06}$ & $\frac{31,4}{9,03}$ & $\frac{18,9}{5,68}$ & 0,93 \\
\hline Выход зерна с початка, \% & $\frac{9,7}{0,16}$ & $\frac{11,3}{0,19}$ & $\frac{9,7}{0,16}$ & 0,31 \\
\hline
\end{tabular}

Наименьшие масса початка (131,1 г), масса зерна с початка $(99,1$ г), масса зерна с растения (87,5 г), масса 1000 зерен (257 г) и выход зерна с початка (75,3 \%) получены в 2016 году. Разница соответственно показателям с 2017 годом составила 36,0 г (27 \%); 47,1 г (48 \%); 49,2 г (56 \%); 13 г (5 \%); выход зерна с початка $12,1 \%$ (таблица 5).

Полученные данные показывают, что длина початка кукурузы по мере интенсификации технологии выращивания (от 111 к 333) увеличивалась по сравнению с контролем на 0,8-1,9 см (5-12 \%), озерненность початка на 46-116 шт. (10-26 \%), масса початка на 9,3-31,8 г (7-23\%), масса зерна с початка на 20,5-48,7 г (21-49 \%), масса зерна с растения на 20,2-53,7 г (23-62 \%), масса 1000 зерен на 20-58 г (8-24 \%), выход зерна с початка на 9,6-16,1 \%. А вот длина невыполненной части початка - уменьшалась от 111 к 333 на $0,5-1,0$ см (29-59\%). 
Таблица 5 - ЭЛЕМЕНТЫ СТРУКТУРЫ УРОЖАЯ КУКУРУЗЫ В ЗАВИСИМОСТИ ОТ ТЕХНОЛОГИИ ВЫРАЩИВАНИЯ, 2016-2017 ГГ.

\begin{tabular}{|c|c|c|c|c|c|c|c|c|}
\hline \multirow[b]{2}{*}{$\begin{array}{c}\text { Индекс } \\
\text { вариан- } \\
\text { та опыта }\end{array}$} & \multicolumn{2}{|c|}{ Длина, см } & \multirow{2}{*}{ 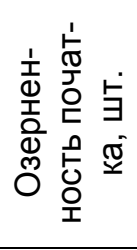 } & \multicolumn{4}{|c|}{ Macca, г } & \multirow{2}{*}{ 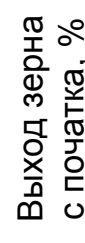 } \\
\hline & $\begin{array}{c}\text { почат- } \\
\text { ка }\end{array}$ & $\begin{array}{c}\text { невыпол- } \\
\text { ненной } \\
\text { части по- } \\
\text { чатка }\end{array}$ & & $\begin{array}{c}\text { почат- } \\
\text { ка }\end{array}$ & $\begin{array}{l}\text { зерна с } \\
\text { початка }\end{array}$ & $\begin{array}{c}\text { зерна с } \\
\text { растения }\end{array}$ & $\begin{array}{c}1000 \\
\text { зерен }\end{array}$ & \\
\hline 000 (к) & 15,4 & 1,7 & 440 & 137,2 & 99,0 & 86,1 & 238 & 71,1 \\
\hline 111 & 16,2 & 1,2 & 486 & 146,5 & 119,5 & 106,3 & 258 & 80,7 \\
\hline 222 & 16,7 & 0,9 & 519 & 155,8 & 132,3 & 123,5 & 278 & 84,4 \\
\hline 333 & 17,3 & 0,7 & 556 & 169,0 & 147,7 & 139,8 & 296 & 87,2 \\
\hline 002 & 15,8 & 1,4 & 454 & 141,4 & 109,4 & 96,0 & 248 & 76,5 \\
\hline 020 & 16,5 & 1,1 & 502 & 149,8 & 126,2 & 116,9 & 269 & 83,6 \\
\hline 022 & 16,6 & 1,1 & 510 & 151,8 & 130,1 & 121,0 & 271 & 85,2 \\
\hline 200 & 16,0 & 1,3 & 467 & 143,4 & 115,1 & 103,1 & 251 & 79,4 \\
\hline 202 & 16,1 & 1,3 & 477 & 144,0 & 117,1 & 106,4 & 254 & 80,4 \\
\hline 220 & 16,7 & 1,1 & 522 & 152,2 & 130,6 & 121,9 & 275 & 85,3 \\
\hline
\end{tabular}

Внесение средней дозы удобрений в среднем по вариантам 020 и 022, как и повышенного фона плодородия почвы на вариантах 200 и202 увеличивало данные показатели по сравнению с контролем. Так, длина початка соответственно вариантам опыта увеличивалась на 1,2-0,7 см (8-5\%), озерненность початка на 66-32 шт. (15-7 \%), масса початка на 13,6-6,5 г (10-5 \%), масса зерна с початка на 29,2-17,1 г (29-17 \%), масса зерна с растения на 32,9-28,7 г (39-22 \%), масса 1000 зерен на 32-15 г (14-6 \%). Лучшие результаты были получены на варианте 220 (повышенный фон почвенного плодородия и средняя доза удобрений) и превышали контроль соответственно показателям на: 1,3 см (8 \%); 82 шт. (19\%); 15,0 г (11\%); 31,6 г (32\%); 35,8 г (42 \%); 37,0 г (16\%); выход зерна с початка 14,2 \%.

В первой ротации севооборота по исследуемым годам наибольшее количество осадков выпало как за 1994-1995 с/х год (826 мм), так и за вегетационный период 1995 года (401 мм), превышая норму на 136 мм или в 
1,5 раза, поэтому урожайность зерна кукурузы в этот год была наибольшей и составила в среднем по вариантам опыта 80,2 ц/га (таблица 6).

Таблица 6 - УРОЖАЙНОСТЬ ЗЕРНА КУКУРУЗЫ В ЗАВИСИМОСТИ ОТ ТЕХНОЛОГИИ ВЫРАЩИВАНИЯ, 1994-1996 гг.

\begin{tabular}{|c|c|c|c|c|c|c|}
\hline \multirow{2}{*}{$\begin{array}{c}\text { Индекс } \\
\text { варианта опыта }\end{array}$} & \multicolumn{4}{|c|}{ Урожайность зерна, ц/га } & \multicolumn{2}{c|}{$\begin{array}{c}\text { Прибавка урожая по } \\
\text { сравнению с контролем }\end{array}$} \\
\cline { 2 - 7 } & 1994 г. & 1995 г. & 1996 г. & $1994-1996$ гг. & ц/га & $\%$ \\
\hline 000 (к) & 38,0 & 65,6 & 13,4 & 39,0 & - & - \\
\hline 111 & 42,1 & 75,2 & 18,2 & 44,5 & 5,5 & 14 \\
\hline 222 & 49,6 & 86,1 & 21,8 & 52,5 & 13,5 & 35 \\
\hline 333 & 53,2 & 88,4 & 24,3 & 55,3 & 16,3 & 42 \\
\hline 002 & 39,6 & 69,4 & 14,8 & 41,3 & 2,3 & 6 \\
\hline 020 & 48,1 & 84,5 & 21,4 & 51,3 & 12,3 & 32 \\
\hline 022 & 46,1 & 83,6 & 20,4 & 50,0 & 11,0 & 28 \\
\hline 200 & 45,9 & 82,5 & 19,7 & 49,4 & 10,4 & 27 \\
\hline 202 & 45,2 & 80,6 & 19,5 & 48,4 & 9,4 & 24 \\
\hline 220 & 48,8 & 86,0 & 21,0 & 51,9 & 12,9 & 33 \\
\hline $\mathrm{HCP}_{05}$ & 1,4 & 4,9 & 1,6 & & & \\
\hline
\end{tabular}

В 1996 году осадков за вегетацию кукурузы выпало 360 мм, превышая норму на 95 мм (36 \%), но в течение июля осадков не было, что и отразилось на урожайности культуры, которая в среднем по вариантам опыта равнялась 19,3 ц/га. Промежуточное положение отмечено в 1994 году (осадков выпало меньше нормы на 66 мм или 33 \%), однако их распределение по месяцам было более или менее равномерно. Поэтому, урожайность зерна в 1994 годы в среднем по вариантам опыта составила 45,7 ц/га. Разница между исследуемыми годами равнялась 34,5 ц/га (75 \%) (1994 год) и 60,9 ц/га (316 \%) (1996 год), по сравнению с 1995 годом.

Анализируя урожайные данные в среднем за 1994-1996 годы, можно отметить, что наименьшим данный показатель был на варианте 000 (экстенсивная технология-контроль) и равнялся 39,0 ц/га. Применение беспестицидной (111), экологически допустимой (222) и интенсивной технологий увеличивало урожайность зерна на 5,5-16,3 ц/га (14-42 \%). Использование только гербицида на варианте 002 повышало урожай на 2,3 ц/га (6\%). Вне- 
сение средней нормы удобрений на вариантах 020 и 022 без применения средств защиты растений и с ними - на 12,3-11,0 ц/га (32-28 \%). Применение повышенного уровня почвенного плодородия на вариантах 200 и $202-$ на 10,4-9,4 ц (27-24 \%). Лучшим было сочетание на варианте 220, где прибавка урожая составила 12,9 ц/га (33 \%).

Во второй ротации севооборота по исследуемым годам наибольшее количество осадков выпало как за 2005-2006 с/х год (759 мм) и за 20042005 c/х год (750 мм), так и за вегетационный период 2006 и 2005 годов (304 и 273 мм), поэтому урожайность зерна кукурузы в эти годы была наибольшей и составила в среднем по вариантам опыта соответственно 72,3-76,1 ц/га. В 2007 году осадков за вегетацию кукурузы выпало 122 мм, что ниже нормы в 2,3 раза, при этом в течение июля осадков выпало всего 4мм, что и отразилось на урожайности культуры, которая в среднем по вариантам опыта равнялась 41,2 ц/га. Разница между исследуемыми годами равнялась 34,9 ц/га (85 \%) (2005 год) и 31,1 ц/га (75 \%) (2006 год), по сравнению с 2007 годом (таблица 7).

Таблица 7 - УРОЖАЙНОСТЬ ЗЕРНА КУКУРУЗЫ В ЗАВИСИМОСТИ ОТ ТЕХНОЛОГИИ ВЫРАЩИВАНИЯ, 2005-2007 гг.

\begin{tabular}{|c|c|c|c|c|c|c|}
\hline \multirow{2}{*}{$\begin{array}{c}\text { Индекс } \\
\text { варианта опыта }\end{array}$} & \multicolumn{5}{|c|}{ Урожайность зерна, ц/га } & \multicolumn{2}{c|}{$\begin{array}{c}\text { Прибавка урожая по } \\
\text { сравнению с контролем }\end{array}$} \\
\cline { 2 - 7 } & 2005 г. & 2006 г. & 2007 г. & $2005-2006$ гг. & ц/га & $\%$ \\
\hline 000 (к) & 55,0 & 59,9 & 33,2 & 49,4 & - & - \\
\hline 111 & 69,5 & 67,0 & 36,6 & 57,7 & 8,3 & 17 \\
\hline 222 & 85,4 & 76,6 & 44,2 & 68,7 & 19,3 & 39 \\
\hline 333 & 98,1 & 91,6 & 52,1 & 80,6 & 31,2 & 63 \\
\hline 002 & 62,9 & 63,4 & 35,7 & 54,0 & 4,6 & 9 \\
\hline 020 & 73,6 & 70,5 & 38,6 & 60,9 & 11,5 & 23 \\
\hline 022 & 76,5 & 72,0 & 40,9 & 63,1 & 13,7 & 28 \\
\hline 200 & 77,9 & 73,0 & 43,5 & 64,8 & 15,4 & 31 \\
\hline 202 & 79,5 & 74,3 & 43,6 & 65,8 & 16,4 & 33 \\
\hline 220 & 82,7 & 75,0 & 43,8 & 67,2 & 17,8 & 36 \\
\hline $\mathrm{HCP}_{05}$ & 7,0 & 6,2 & 3,0 & \multicolumn{3}{|c|}{} \\
\hline
\end{tabular}


Анализируя урожайные данные в среднем за 2005-2007 годы, можно отметить, что наименьшим данный показатель был на варианте 000 (экстенсивная технология-контроль) и равнялся 49,4 ц/га. Применение беспестицидной (111), экологически допустимой (222) и интенсивной технологий увеличивало урожайность зерна на 8,3-31,2 ц/га (17-63 \%). Использование только гербицида на варианте 002 повышало урожай на 4,6 ц/га (9 \%). Внесение средней нормы удобрений на вариантах 020 и 022 без применения средств защиты растений и с ними - на 11,5-13,7ц/га (23-28 \%). Применение повышенного уровня почвенного плодородия на вариантах 200 и $202-$ на 15,4-16,4 ц (31-33 \%). Лучшим было сочетание на варианте 220, где прибавка урожая составила 17,8 ц/га (36 \%).

В третьей ротации севооборота по исследуемым годам осадков выпало больше нормы, как за с/х год, так и за вегетацию кукурузы. В 20152016 c/х год количество осадков составило (726 мм), в 2016-2017 c/х год (693 мм), что превышало норму соответственно на 112-79 мм (18-13 \%). За вегетацию растений осадков выпало 290 мм (2016 г.) и 337 мм (2017 г.), превышая норму в 1,1-1,3 раза. Наибольшая урожайность зерна получена в 2017 году и в среднем по вариантам опыта равнялась 66,2 ц/га, что больше на 14 ц/га (27 \%), чем в 2016 году (таблица 8).

Таблица 8 - УРОЖАЙНОСТЬ ЗЕРНА КУКУРУЗЫ В ЗАВИСИМОСТИ ОТ ТЕХНОЛОГИИ ВЫРАЩИВАНИЯ, 2016-2017 гГ.

\begin{tabular}{|c|c|c|c|c|c|}
\hline \multirow{2}{*}{$\begin{array}{c}\text { Индекс } \\
\text { варианта } \\
\text { опыта }\end{array}$} & \multicolumn{3}{|c|}{ Урожайность зерна, ц/га } & \multicolumn{2}{c|}{$\begin{array}{c}\text { Прибавка урожая по } \\
\text { сравнению с контролем }\end{array}$} \\
\cline { 2 - 6 } & 2016 г. & 2017 г. & $2016-2017$ гг. & ц/га & $\%$ \\
\hline 000 (к) & 35,3 & 54,1 & 44,7 & - & - \\
\hline 111 & 48,4 & 59,9 & 54,2 & 9,5 & 21 \\
\hline 222 & 58,8 & 71,6 & 65,2 & 20,5 & 46 \\
\hline 333 & 74,0 & 79,2 & 76,6 & 31,9 & 71 \\
\hline 002 & 42,5 & 55,1 & 48,8 & 4,1 & 9 \\
\hline 020 & 54,5 & 69,2 & 61,9 & 17,2 & 38 \\
\hline 022 & 57,5 & 70,3 & 63,9 & 19,2 & 43 \\
\hline 200 & 45,8 & 63,8 & 54,8 & 10,1 & 23 \\
\hline 202 & 46,5 & 67,2 & 56,9 & 12,2 & 27 \\
\hline 220 & 58,4 & 71,4 & 64,9 & 20,2 & 45 \\
\hline $\mathrm{HCP}_{05}$ & 10,4 & 4,7 & \multicolumn{3}{|c}{} \\
\hline
\end{tabular}


По нашим данным, полученным в среднем за 2016-2017 годы, можно отметить, что наименьшим данный показатель был на варианте 000 (экстенсивная технология-контроль) и равнялся 44,7 ц/га. Применение беспестицидной (111), экологически допустимой (222) и интенсивной технологий увеличивало урожайность зерна на 9,5-31,9 ц/га (21-71 \%). Использование только гербицида на варианте 002 повышало урожай на 4,1 ц/га (9 \%). Внесение средней нормы удобрений на вариантах 020 и 022 без применения средств защиты растений и с ними - на 17,2-19,2 ц/га (38-43 \%). Применение повышенного уровня почвенного плодородия на вариантах 200 и $202-$ на 10,1-12,2ц (23-27 \%). Лучшим было сочетание на варианте 220, где прибавка урожая составила 20,2 ц/га (45 \%).

Множественный коэффициент корреляции был достаточно большой $(\mathrm{R}=0,79-0,95)$, что говорит о высокой зависимости урожайности зерна от изучаемых факторов. Результатами пошагового множественного регрессионного анализа установлено, что наибольшая зависимость урожая зерна получена от системы удобрения, где доля влияния составила по ротациям севооборота 38,9-32,7 \%, далее было влияние уровня почвенного плодородия 29,7-46,5 \%, на последнем месте было влияние системы защиты растений $10,7-15,3 \%$.

Таблица 9 - МНОЖЕСТВЕННАЯ РЕГРЕССИОННАЯ ЗАВИСИМОСТЬ УРОЖАЙНОСТИ ЗЕРНА КУКУРУЗЫ В ЗАВИСИМОСТИ ОТ ТЕХНОЛОГИИ ВЫРАЩИВАНИЯ

\begin{tabular}{|l|c|c|c|c|}
\hline \multirow{2}{*}{$\begin{array}{c}\text { Урожайность зерна по ротациям } \\
\text { севооборота, ц/га }\end{array}$} & \multicolumn{3}{|c|}{$\begin{array}{c}\text { Доли влияния и коэсрфициенты } \\
\text { регрессии по факторам }\end{array}$} & \multirow{2}{*}{$\mathrm{R}$} \\
\cline { 2 - 4 } & $\mathrm{A}$ & $\mathrm{B}$ & $\mathrm{C}$ & \\
\hline $1994-1996$ гг. & $\frac{29,7}{1,84}$ & $\frac{38,9}{1,72}$ & $\frac{10,7}{1,44}$ & 0,79 \\
\hline $2005-2007$ гг. & $\frac{46,5}{5,76}$ & $\frac{32,7}{4,11}$ & $\frac{15,3}{2,04}$ & 0,95 \\
\hline
\end{tabular}


Таким образом, на основании трех ротаций севооборота, можно сделать вывод, что значительное влияние на элементы структуры урожая и урожайность зерна кукурузы оказывают погодные условия исследуемых лет, особенно наличие осадков в критический по водопотреблению период (июль). Интенсификация средств химизации земледелия способствовала существенному увеличению всех представленных показателей, достигая наибольших значений при интенсивной технологии выращивания (вариант $333)$ в первой ротации севооборота (1994-1996 гг.) - 55,3 ц/га, во второй ротации (2005-2007 гг.) - 80,6 ц/га, в третьей ротации - 76,6 ц/га. Разница с контролем составила соответственно ротациям севооборота 16,3 ц/га (42\%), 31,2 ц/га (63\%) и 31,9 ц/га (71\%). Причем, следует отметить, что чем более увлажненными были годы опыта, тем более высокий эффект получен от внесения удобрений.

\section{СПИСОК ИСПОЛЬЗОВАНИЙ ЛИТЕРАТУРЫ}

1. Алабушев В. А. Растениеводство / В. А. Алабушев. - Ростов н/Д: Издательский центр «Март», 2001. - 230 с.

2. Андреенко, С. С. Физиология кукурузы / С. С. Андреенко, Ф. М. Куперман.М., 1959.- 289 с.

3. Вербицкая Н. М. Формирование высокопродуктивных посевов кукурузы на зерно / Н. М. Вербицкая. - М., 1983. - 57 с.

4. Исакова С.В. Урожайность зерна кукурузы в зависимости от некорневых подкормок в зоне неустойчтвого увлажнения Краснодарского края / С.В. Исакова, А.А. Макаренко, Т.В. Логойда // Сб. статей по матер. Х Всерос. конф. мол. ученых, посвященной 120-летию И.С. Косенко. - Краснодар, 2017. - С. 868-869.

5. Кукуруза (выращивание, уборка, консервирование и использование) / Под ред. Д. Шпаара. - 3-е изд., дораб. и доп. - М.: Колос, 2006. - 363 с.

6. Куренной И.А. Влияние технологии выращивания на урожайность зерна кукурузы в центральной зоне Краснодарского края / И.А. Куренной, С.И. Новоселецкий, И.С. Сысенко // в сб. Научное обеспечение АПК : сб. ст. по матер. 72-й научн.-практ. конф. студентов по итогам НИР за 2016 год. - Краснодар, 2017. - С. 13-15.

\section{References}

1. Alabushev V. A. Rastenievodstvo / V. A. Alabushev. - Rostov n/D: Izdatel'skij centr «Mart», 2001. - $230 \mathrm{~s}$.

2. Andreenko, S. S. Fiziologija kukuruzy / S. S. Andreenko, F. M. Kuperman.-M., 1959.- $289 \mathrm{~s}$.

3. Verbickaja N. M. Formirovanie vysokoproduktivnyh posevov kukuruzy na zerno / N. M. Verbickaja. - M., 1983. - 57 s. 
4. Isakova S.V. Urozhajnost' zerna kukuruzy $\mathrm{v}$ zavisimosti ot nekornevyh podkormok v zone neustojchtvogo uvlazhnenija Krasnodarskogo kraja / S.V. Isakova, A.A. Makarenko, T.V. Logojda // Sb. statej po mater. H Vseros. konf. mol. uchenyh, posvjashhennoj 120-letiju I.S. Kosenko. - Krasnodar, 2017. - S. 868-869.

5. Kukuruza (vyrashhivanie, uborka, konservirovanie i ispol'zovanie) / Pod red. D. Shpaara. - 3-e izd., dorab. i dop. - M.: Kolos, 2006. - 363 s.

6. Kurennoj I.A. Vlijanie tehnologii vyrashhivanija na urozhajnost' zerna kukuruzy v central'noj zone Krasnodarskogo kraja / I.A. Kurennoj, S.I. Novoseleckij, I.S. Sysenko // v sb. Nauchnoe obespechenie APK : sb. st. po mater. 72-j nauchn.-prakt. konf. studentov po itogam NIR za 2016 god. - Krasnodar, 2017. - S. 13-15. 